\title{
THE ENDS OF ISLAMIC ECONOMICS FROM THE PERSPECTIVE OF HOMO ECONOMICUS AND HOMO ISLAMICUS: A CRITICAL STUDY
}

\author{
Satria Hibatal Azizy \\ Mohd Mahyudi, Mohd Yusop \\ International Islamic University Malaysia \\ hibatalazizy@gmail.com
}

\begin{abstract}
This paper compares the ends of economic from homo economicusand homo Islamicusperspective. It is a literature study that is combined with the argumentative approach in order to provide the valid comparison of these two. The end or the goal of economics is one of important component of microfoundations of economics. It will become one deciding factor in chosing the most suitable economic agent for Islamic economics. The result of this study shows that the end of economics from homo economicusperspective, which is maximization of utility, is facing a huge criticism. The same case is shown in the end of economics from homo Islamicusperspective, which is maximization of maslahah. This paper later suggests the use of incremental welfare value as the end of economics.
\end{abstract}

Keywords: Islamic Economic, Homo Economicus and Homo Islamicus

\section{A. Introduction}

The idea of "economic man" has become an interesting discussion in current development of economics as a branch of social science. Homo economicus, which is considered a mainstream economic agent of modern economic system, is facing many 
criticisms from various angles. The use of homo economicus has long been criticized by western economists, such as Pettit, Gintis, and Roberts. Pettit considers homo economicus that is equipped with virtual self-regard may not be relevant in explaining the emergence of any pattern of behaviour. ${ }^{1}$ From experimental economics point of view, real-life humans are hopelessly irrational if the idea of rationality of homo economicus implies self-interest, outcome orientation and time consistency. ${ }^{2}$ Moreover, Robertsargues that Homo economicus is simply making men and women pieces on a chessboard which restrict the understanding of their action. ${ }^{3}$ Human being is a complicated creature which could not be understood by simple premises. These arguments show several shortcomings of homo economicus.

As for the case of Islamic economics (IE), it offers a solution to solve the problem of economic man. It has a unique economic man called homo Islamicus. This man is conceptualized as a paragon of virtue given that it is based on positive traits of man found in the primary sources. ${ }^{4}$ Literally, homo Islamicus means Islamic man. It can be defined as the individual who acts in accordance to the norms of Islam as outlined in the al-Quran and Sunnah in his daily life. This man, as identified by Furqani, is a man constructed within the framework of Islamic economics with its own micro-foundation. ${ }^{5}$

However, the concept of homo Islamicus is also facing huge criticism, even from Muslim economists themselves. It is because the current economic man for Islamic economics, which is homo Islamicus, is not really functioning in the real world. Homo Islamicus, which is supposed to be economic man for Islamic economics, fails because it is impossible to live up to the ideal of it. ${ }^{6}$ It is too simplistic and

\footnotetext{
${ }^{1}$ P. Pettit, The Virtual Reality of Homo Economicus (The Monist, 1995).

${ }^{2}$ H,Gintis, Beyond Homo Economicus: Evidence from Experimental Economics. (Ecological Economics, 35, 2000).

${ }^{3}$ Roberts R., "Sympathy for Homo Religious," Econ Journal Watch, 11, 2 (2014): p.231.

${ }^{4}$ Mahyudi.Mohd., True Man': The True Economic Man for Islamic Economics (,GJAT, 2015).p.67

${ }^{5}$ HafasFurqani. (2015). "Individual and Society in an Islamic Ethical Framework: Exploring Key Terminologies and the Micro-Foundations of Islamic Economics." Humanomics Vol. 31 No. 1, p. 77-82.

${ }^{6}$ Kuran, T. (1996). The discontents of Islamic economic morality. AEA Papers and Proceedings: Linkages Between Economics and Religion, 88(2), p. 442.
} 
unrealistic. Even greed and selfishness, which are the features of homo economicus, are closer to the reality than altruistic homo Islamicus. ${ }^{7}$ The intention to make Homo Islamicus as an ideal representative of Islamic values has fell through since the reality proved that the soul of homo economicus is trampling over homo Islamicus. ${ }^{8}$

One thing that could be deemed as the cause of these criticisms is the microfoundations of economics that is not really suited with the reality. In order to build the economic agent for Islamic economics, there is a need to formulate the correctmicrofoundations that can be utilized in the real world. As stated byFurqani, the microfoundations of Islamic economics consist of the end or motive, mean or basis and cardinal virtue. ${ }^{9}$ Therefore, there is a need to address each point of the microfoundations so that the most suitable economic agent can be formulated.

This paper will try to explore the end or the goal of the economics from homo economicus and homo Islamicus perspective. The end of economics is important because it is the basis of the actions that are performed by each economic agent. If the end of economics is correctly formulated, the most suitable economic agent for Islamic economics will be easier to be defined.

\section{B. The End of Economics From Homo Economicus Perspective}

The ends of homo economicus is maximization of utility. Maximization is a postulates that exist in the economy. Maximizing postulate is the sense that individual's decision making is guided by

${ }^{7}$ Hosseini, H. (1992). From homo economicus to homo Islamicus: the universality of economic science reconsidered. In: Bina, C. \&Zanageh, H. (Eds.). (1992). Modern Capitalism and Islamic Ideology in Iran. St. Martin's Press, New York, USA.

${ }^{8}$ Concluded from the arguments of Asutay, M. (2007). Conceptualisation of the second best solution in overcoming the social failure of Islamic finance: Examining the overpowering of homoislamicus by homoeconomicus. IIUM Journal of Economics and Management 15, no. 2 (2007): 167-195; also at Farooq, M. O. (2011). Self-interest, Homo Islamicus and Some Behavioral Assumptions in Islamic Economics and finance. International Journal of Excellence in Islamic Banking and Finance, 1(1), 52-79; and at Shams, R. (2004). "A Critical Assessment of Islamic Economics." 281. Hamburg, Germany.

${ }^{9}$ Furqani.... p. 75 
maximising an objective function subject to constraint. ${ }^{10}$ Economists often assume the complete knowledge and perfect foresight in order to reach the objective of maximization, which in economics are often described as profit and utility. Maximization postulates is very important. It is because individuals are more likely to survive if they apply maximization rule. ${ }^{11}$ Individuals with the maximization rule tend to be superior in term of seeking a best alternative to reach his/ her target. It is safe to say that maximizing postulate is an integrated part in economics that cannot be ignored.

Since profit is the focus of a firm, the end of economic activity itself is to gain maximum utility. Utility in plain English means usefulness. ${ }^{12}$ Furthermore, Bentham and Mill uses the word 'utility' as a short name for 'the greatest happiness principle'. ${ }^{13}$ As an addition, utility also can be seen as "the thing that the principles are concerned with promoting, viz., pleasure minus pain. ${ }^{14}$ According to Sen, Bentham is rather worried that the term "utility" cannot bear the mean that he intended, since what he wants is a word that can describe pleasure and pain. ${ }^{15}$ Once again, Mill also warns against this issue. He said that utility is not only a pleasure, but pleasure itself with exemption from pain. ${ }^{16}$

The concept of maximization of utility in economics is almost as old as economics itself. ${ }^{17}$ Essentially, the concept of utility can be traced back to the moral philosopher Jeremy Bentham in the late eighteen century..$^{18}$ Bentham said that utility is

${ }^{10}$ Van Witteloostuijn, A. (1988). Maximising and satisficing opposite or equivalent concepts? Journal of Economic Psychology. 9(3), p. 294.

${ }^{11}$ Friedman, 1953, at Van Witteloostuijn... p. 308

12 Broome, J. (1991). Utility. Economics and Philosophy, 7(01), p. 1.

${ }^{13}$ Broome... p. 1. 7(2), p. 280.

${ }^{14}$ Sen, A. (1991). Utility: ideas and terminology. Economics and Philosophy,

${ }^{15}$ Sen... p. 280

${ }^{16}$ Sen...... p. 281

${ }^{17}$ Gilad, B., Kaish, S., Loeb, P.D. (1987). Cognitive dissonance and utility maximization: a general framework. Journal of Economic Behaviour and Organization, 8, p. 61.

${ }^{18}$ Juster, F.T. (1990). Rethinking Utility Theory. The Journal of Behavioural Economics. 19(2), p. 156. 
"the property in any object, whereby it tends to produce benefit, advantage, pleasure, good, or happiness, or to prevent the happening of mischief, pain, evil or unhappiness to the party whose interest is considered". ${ }^{19}$

Whereas Mill never identifies utility with pleasure or happiness, even though there are some worded remarks in his writing that suggest he does. ${ }^{20}$ Mill used the word "utility" to describe a principle that considered as directive rule of human conduct. ${ }^{21}$ People who subscribe to this idea are called utilitarians.

Furthermore, Hart describes Bentham's opinion which he explicitly identifies utility as maximization of pleasure and happiness come from any sources. Other economists like Hazlitt, Carlyle and Dickens contrast utility with enjoyment of life and happiness. They stated that it means merely the production of material goods at the cost of grinding labour. ${ }^{22}$ To put it simple, utility itself is a satisfaction in the form of pleasure and happiness which is free from pain and misery.

It is then being integrated into economic analysis by Jevons, Menger and Walras in 1870s. It is marked by the publication of Jevon's Theory of Political Economy. In this writing, Jevon quotes Bentham's definition of utility and stated that the definition is a perfect expression for the meaning of the term in the economy. ${ }^{23}$ In this time also the concept of marginal utility was developed. According to them, utility measured is utility for consumption of goods by an individual being. Later, Robbins and Hicks develop this concept and says that the utility measured was not merely goods, but goods and leisure. ${ }^{24}$

In the modern days, utility is often defined as the representation of a person's preferences. ${ }^{25}$ This simple definition is given in major economic textbooks, such as Debreu and Deaton and

\footnotetext{
${ }^{19}$ In Broome...... p. 1

${ }^{20}$ Broome....... p. 1

${ }^{21}$ Broome...... p. 1

${ }^{22}$ Hart, 1987 at Sen...... p. 282

${ }^{23}$ Broome...... p. 1

${ }^{24}$ Juster...... p. 157

${ }^{25}$ Broome...... p. 5
} 
Muellbauer. It is a technical term that is used in theoretical economics and universally accepted. Basically, it is a preference of a person if he/she faced with choices. He/she will always pick what is best for him/her. It is universally accepted that the concept of utility requires self-interested and rational being as economic agent. ${ }^{26}$ In other word, utility in the present days often understood as the representation of homo economicus' preferences.

From these paragraphs, it can be seen that utility is focused on the material and measurable things of an individual. Every human being act as a consumer to fulfil his wants. In its purest form, utility are measured at the individual level and reduces to an empirical and quantifiable pleasure. ${ }^{27}$ It is acceptable in any form, as long as it can bring satisfaction to an individual. ${ }^{28}$ It might be anything, even though it is forbidden by religion or society. The utility maximizer will always try to obtain maximum satisfaction with no regard to norms and religious value. It is to realize the goal of utility maximization as the ultimate goal of economic activity. ${ }^{29}$ The basis point of utility is individual desire and wants, while its goal is individual satisfaction. Its calculation is based on the calculus of pleasure and pain. Homo economicus, therefore, will always try to maximize his own pleasure with no regard to others. ${ }^{30}$

By implementing the purest form of maximization of utility as his/her end, homo economicus will have a self-centered characteristic. $\mathrm{He} /$ she will always try to improve his/her pleasure, without moral considerations. He/she will avoid altruism, since their main focus is how to please him/herself. He/she will abandon safekeeping of the nature, because it can decrease their material well-being. This human being will ignore others, since every action is approved or disapproved based on the perceived pain and pleasure experienced

\footnotetext{
${ }^{26}$ Broome...... p. 6

${ }^{27}$ Furqani...... p. 81

${ }^{28}$ Broome...... p. 5

29 Hossain, B. (2014). Economic rationalism and consumption: Islamic perspective. International Journal of Economics, Finance and Management. 3(6), p. 274.

${ }^{30}$ Broome...... p. 4
} 
by an individual. ${ }^{31}$ In short, homo economicus is an egoistic being who aim to please himself without moral or religious consideration.

\section{The End of Economics From Homo Islamicus Perspective}

Homo Islamicus has a different end compared to homo economicus. This difference is due to the paradigm shift that occurred in Islamic economics. Thus, the terminology shift is imminent. It is because the success of the construction of Islamic economic paradigm is strongly related with the ability to create a clear and rigorous language. ${ }^{32}$ In other words, the terminology shift is a very important part of Islamic economics development. ${ }^{33}$ Besides, English language is deemed inadequate to explain the nature of human behaviour. Therefore homo Islamicus, as economic agent for Islamic economics, must has a distinctive end in contrast with homo economicus.

As understood from Furqani, the end of homo Islamicus is maximization of maslahah. ${ }^{34}$ In this point, there are two main ingredients, namely maximization and maslahah. Maximization theory has been rejected by some Muslim economist, such as Siddiqi. ${ }^{35} \mathrm{He}$ said that maximization hypothesis is not very helpful in understanding the economy. On the other side, it is approved by other Muslim economists, such as Hasan. He stated that maximization per $s e$ is value neutral. ${ }^{36}$ Maximization hypothesis is more like directional concept. This hypothesis is used to enhance profits and utility. It can be said that it is used to increase efficiency. It is very unlikely that a person or a firm can reach a maximum point of utility or profit. The realized point may fall short behind the maximum point, or it can even be negative. But the nature of human being is always wanting

\footnotetext{
${ }^{31}$ Furqani...... p. 81

${ }^{32}$ AlparslanAcikgenc. (1996). Islamic Science, Towards a Definition. Kuala Lumpur: ISTAC, 1996., also at Abbas Mirakhor. (2007). A Note on Islamic Economics. Jeddah: IRTI, 2007

${ }^{33}$ Furqani...... p. 76

${ }^{34}$ Furqani...... p. 80

${ }^{35}$ Nejatullah Siddiqi. (1998): Teaching Economics in Islamic Perspective, Jeddah: Scientific Publishing Centre, King Abdulaziz University. In ZubairHasan. (2011). Scarcity, self-interest and maximization from Islamic angle. MPRA Paper. No. 29414, posted 08. March 2011 / 06:20

${ }^{36}$ Hasan...... p. 20
} 
8| Satria Hibatal Azizy, Mohd Mahyudi, Mohd Yusop

the best. Since he or she is having such a behaviour, the planning will take place and human being will always plan for the best. It is very unlikely that he or she will plan to fail.

It is further ensured by Furqani. In order to accept maximization hypothesis, the following points must be examined:

a. What is to be maximized, utility or Maslahah, pain/pleasure or beneficial/harmful?

b. What for is the maximization, self-satisfaction/pleasure or self-actualization/transformation?

c. Instruments or means to achieve them. ${ }^{37}$

In short, it must be known beforehand what to maximize, how to maximize and what for the maximization. After understanding these points, Furqani states that the concept of maximization in IE corresponds with the Islamic concept of success and progress, the Islamic principle of balance and moderation, and the Islamic concept of the nature of human being, his existence's purpose and welfare. ${ }^{38}$

The second point is Maslahah. Maslahah is a terminology that is very often used in Islamic studies. Maslahah is interpreted as a benefit desired by Allah for His servants to keep his faith, his soul, his intellect, his posterity, and his property in accordance with the order described by Him. ${ }^{39}$ The benefit contained in any law specified by him in two forms, namely to provide benefits to humans and protect them from damage and hazardous conditions. ${ }^{40}$ In other words, every law contains maslahah in which each maslahah imply for the achievement of human welfare embodied in the progress of society. ${ }^{41}$ The welfare is manifested on the obtained benefits and the eliminated damage.

\footnotetext{
${ }^{37}$ Furqani...... p. 80

${ }^{38}$ Furqani...... p. 81

39 Al-Buthi, M.S.R. (1973). Dhawabith Al-Maslahah Fi Asy-Syariah AlIslamiyyah, Damaskus, MuassasahAr-Risalah. p. 23

${ }^{40}$ Az-Zuhaili, W. (2001). At-Tafsir al-Wasit. Juz II, Damaskus: Dar al-Fikr, p. 1017

${ }^{41}$ Wan MohdNor Wan Daud, BudayallmudanGagasan 1 Malaysia Membina Negara MajudanBahagia, (Putrajaya: AkademiKenegaraan BTN, 2011). p. 3
} 
Maslahah in sharia at least has three main characteristics. First, maslahah is not just limited to maslahahdunyawiyyah (worldly affairs), but also to maslahahdiniyyah (religious purposes) as well. ${ }^{42}$ All decisions of the existing law should be based on the Qur'an and Sunnah Nabawiyya. If there is a conflict between human interests with the interests of religion, or the Al-Qur'an and Sunnah, then what is contained in the Qur' an and Sunnah shall take precedence. This is because Allah is established all the mundane rules of the Qur'an and Sunnah to human welfare in the world that can lead to welfare in the Hereafter. ${ }^{43}$

The second characteristic, maslahah is not just an element of physical, but also consider the metaphysical elements. In simpler language, maslahah includes not only the physical welfare, but also inner wellbeing. In the life of the world, human needs not only physical welfare alone, but requires also the spiritual welfare, peace of mind and inner happiness. It is human nature that cannot be bargained. The third characteristic, maslahah determination is not limited to the life of the world, but also the life in the hereafter. Thus, when a mujtahid was doing ijtihad to make a legal decision, it should also consider the consequences that would happen in the world and also in the hereafter. Thus, the resulting legal products can be beneficial for all mankind to prosper in this world and in the hereafter. ${ }^{44}$

After understanding those two points, the understanding of maximization of maslahah could be easier. As argued by Furqani, homo Islamicus' end is maximization of maslahah. ${ }^{45}$ As can be understood earlier, maslahah is more toward providing benefit and protection from damage. ${ }^{46}$ Its focus is not merely wordly affair, but also strongly related to the other-wordly affairs. For homo Islamicus, a choice is decided by calculating both benefit and damage that can

\footnotetext{
${ }^{42}$ Al-Buthi...... p. 23

${ }^{43}$ Azizy, S.H. (2014). Mendudukkan Kembali Makna Kesejahteraan dalam Islam. Ponorogo: Center for Islamic and Occidental Studies. p. 7

${ }^{44}$ Al-Buthi...... p. 58

${ }^{45}$ Furqani...... p. 80

${ }^{46}$ Azizy...... p. 10
} 
affect oneself and others. ${ }^{47}$ It is also considering whether it has a contribution to the ukhrawi matters or not. By using maximization of maslahah, any kind of immoral actions, excessive exploitation and unmoral behaviour are eradicated. It also will strongly consider halal and haram characteristic in every goods and services utilized. Besides, the concept of maslahah is not only considering human dimension, but also environmental dimension is getting attention too.

By using those consideration, homo Islamicus has a very unique features. He/she will consume only halal and tayyib goods and services (QS. 2:168), there will be no wasteful spending (QS. $6: 141 ; 17 ; 27)$, the generosity among human being is imminent (QS. 25:67), there will be no hedonistic lifestyle (QS. 89:20) etc. In short, this human being is a spiritual human being, whose his/her ultimate motive is God-centered. He/she will always try to be better human through self-betterment and self-realization. His/her actions will not be self-oriented, but others and nature-oriented.

\section{Analysis on Both Ends of Economics}

The first thing that should be analysed in the above discussion is the maximization postulate. The criticism for this postulate has been done by various economist. As mentioned before, this postulate will assume complete knowledge and perfect foresight toward choices. It is practically very unlikely to happen. According to Simon, there are several limitation to maximizing postulate. ${ }^{48}$

Risk and uncertainty are the first problem appeared at this postulate. Risk here means theories that analyse the probability distribution of the consequences of each alternatives. Uncertainty means theories that assume that the consequences from each alternatives are well-analysed, but the decision maker cannot make the definite decision because he is not able to guarantee the

${ }^{47}$ Furqani...... p. 81

${ }^{48}$ Simon, H. A. (1972). Theories of bounded rationality. In C.B. McGuire et.al. (Ed). Decision and organization. Amsterdam: North-Holland Publishing Company, p. 162. 
occurrence of a certain consequences. ${ }^{49}$ These two things will make calculation of the formula more complex and more difficult to solve.

Another limitation of maximizing postulate is incomplete information about alternatives. There are various models made to deal with this shortcomings. But according to Simon there are still problems in those models. The models that are built to solve this problem include the alternatives available. But the problem arising here is how to select the best alternative among those choices. Moreover, the next question asked is how much effort should be used to find the best alternative..$^{50}$

Finally, the shortcoming of maximizing postulate is complexity. The complexity here means the complexity of the cost function or other environmental constraints which can prevent economic agent to find the best course of action. ${ }^{51}$ This shortcoming is tried to be solved by using numerical analysis, specifically theory of approximation. By introducing this theory, the problem could be reduced and it can be transformed into a theory of an optimal approximation. ${ }^{52}$ This view marked the birth of economic behaviourism.

Furthermore, behaviourist proposes new postulate to replace maximization notion, which is called satisficing principles. ${ }^{53}$ Simon, as a founding father of economic behaviourism, was a pioneer to this principles. In explaining satisficing, he said:

"Satisficing approaches seek this simplification in a somewhat different direction, retaining more of the detail of the real world situation, but settling for a satisfactory, rather than an approximate best, decision. One cannot predict in general which approach will lead to the better decision as measured by their real-world consequences". ${ }^{54}$

From above statement, it can be understood that satisficing principle will take into consideration what happens in the reality. It will seek an alternative in which can bring him satisfaction.

\footnotetext{
${ }^{49}$ March and Simon, 1958 at Von Wittloostuijn...... p. 292

${ }^{50}$ Simon...... p. 165

${ }^{51}$ Simon...... p. 168

${ }^{52}$ Simon...... p.169

${ }^{53}$ Von Witteloostuijn...... p. 291

${ }^{54}$ Simon...... p. 170
}

Jurnal Hukum dan Ekonomi Syariah, Vol. 07 | Nomor 1 
It is because there is no certainty in the real world and satisficing principle will bring a sufficient satisfaction for an economic agent. By implementing satisficing principle, an economic man will not try to find "the maximum point", but he/she feels sufficient with some point that he finds satisfactory.

After rejecting maximizing postulate, universal man also does not approve utility. Utility, as mentioned before, has many weaknesses. Utility is a concept which has many understanding, and therefore, it is difficult to find a concise and agreeable meaning among economists. ${ }^{55}$ It could be pleasure minus pain ${ }^{56}$, fulfilment of desire ${ }^{57}$ or even preference. If it means preference, a person's preference is uncertain, let alone all the people. It will make the study of economics ambiguous and difficult to follow.

This confusion in definition will bring utility to the next problem. It will be very difficult to ascertain whether a thing is fulfilling one's utility or not. According to homo economicus, donating money to charity will not add one's wealth. It will decrease his wealth instead. But in reality, most wealthy people donates his money to other parties. ${ }^{58}$ Another example, the love a parent to their children. A parent will always do what is best for their children, even if it means sacrificing him/herself. In this sense, even the most rational human being will act against utility maximization theory.

Other example that can be pointed out here is the concern for the nature. Despite many human being that does not care for the nature, there are other human being who are very concerned for the nature. There are many NGOs to take care of nature, such as NGO to keep endangered animal, NGO to care the forest etc. This reality proves that human being is not homo economicus who only concerned for himself. Human being is not a self-centered being like what ought to be claimed by homo economicus. Human being is a being that care for others and his surroundings.

\footnotetext{
${ }^{55}$ Broome...... p. 3 and Sen...... p. 277

${ }^{56}$ Sen...... p. 280

${ }^{57}$ Sen...... p. 278

${ }^{58}$ Hossain...... p. 274
} 
For the case of maslahah, universal man does not reject it. But as for the end of universal man, the concept of maslahah at its purest form is not used. Maslahah is very wide concept which its main goal is the welfare of human being. ${ }^{59}$ But the use of maximization of maslahah is quite unrealistic. As mentioned by Mahyudi, the traits that are found in homo Islamicus are paragon of virtue that is predominantly based on positive traits found in Quran and Sunnah. ${ }^{60}$ Universal man also agree with these traits, since universal man is an economic agent designed for Islamic economics. Unfortunately, there are missing traits that homo Islamicus failed to identify. Those traits are the bad traits of human being. At this point, the similar problem with utility arises.

The problem with utility is the unrealistic behaviour of homo economicus. Maslahah also has the same problem. Homo Islamicus who uses maslahah at its best, will always consider other-wordly affair as its consideration. ${ }^{61} \mathrm{He} /$ she also will not think for the sake of him/herself, but will always think of others and nature. But in reality, there are human beings who only think about himself. There are human being who does not care about nature. There are also human being that does not care about the life after death. At the end, homo Islamicus is like a "utopian citizen in an imaginary country", since it will be very difficult to find such a man in the real world.

Besides, by implementing maslahah, non-muslim people will try to alienate themselves from embarking Islamic economics. This problem underlined by Khan. He says that Islamic economics should open its audiences and not only limit it within the scope of muslim, but to all society around the world. ${ }^{62}$ This idea is supported by Kahf. He questioned the necessity the use of "Islamic" prefix to economics. He wants Islamic economics be widely accepted and therefore, he

${ }^{59}$ Azizy...... p. 14
${ }^{60}$ Mahyudi..... p. 67
${ }^{61}$ Azizy...... p. 12
${ }^{62}$ Khan, M.A. (2013). Reconstruction of Economics Based on the Paradigm of Tawhid: Present Challenges and Future Prospects. Keynote address for the First World Congress on Integration and Islamicisation of Acquired Human Knowledge. IIUM Malaysia. p. 24 


\section{4| Satria Hibatal Azizy, Mohd Mahyudi, Mohd Yusop}

erase the word Islamic from his definition of economics. ${ }^{63}$ The use of maslahah, which is an Islamic term, will not be easily understood by non-muslim. Moreover, maslahah requires other-worldly orientation, which non-muslim does not believe to that. As a religion of rahmatanlil 'alamin, Islamic economics should embark all people and not only limited to muslim.

From those arguments, the more realistic end is called incremental welfare improvement. This hypothesis is quite similar with the satisficing principle. This hypothesis is introduced by Mahyudi and Aziz. According to them, incremental welfare improvement is a condition where an economic agent improves his welfare through alternatives that would make him better off than before. ${ }^{64}$ In this condition, every kind of human being can be accommodated. Human being that more towards maximization of utility will try to achieve the highest utility possible. Human being that tend to be more homo Islamicus will try to obtain Maslahah as high as possible. Whereas the average human being can be accommodated too by using this hypothesis, since this hypothesis does not require a certain level of maximization or any level of satisficing. This hypothesis seems to be more reflective of all economic transaction.

\section{E. Conclusion}

The more suitable end for economics is incremental welfare. It is because maximization of utility and maximization of maslahah as the ends of homo economicus and homo Islamicus; respectively, have failed to depict the reality of human being's economic pursuit. It is also because maximization postulate has several limitations. The first limitation is risk and uncertainty that happens while calculating the maximization formula. These two things would definitely make the problem solving process more complex and difficult. The second

${ }^{63}$ Kahf, M. (2003). Islamic economics: notes on definition and methodology. Review of Islamic Economics. 13, p. 42.

${ }^{64}$ Mahyudi, M., Aziz, E. A. (2017). Rethinking the structure of Islamic economic science: the universal man imperative. International Journal of Economics, Management and Accounting. 25(2), p. 241 
limitation is incomplete information about the alternatives. This situation would make the decision makers be in a confused state of mind in order to decide which alternative is the best among the choices. The third shortcoming of the maximization goal is complexity. It refers to the scenario where complexity of cost function and other environmental constraints are present in the process of decision making. This complexity displays that the economic agent would be in a very complicated situation every time he deals with a possible economic transaction.

In the case of utility and maslahah, the problem is quite similar as it relates to expectation of an unrealistic behaviour among the typical economic agents. Not all people in the world consider maximization of utility as their ends. At the same time, maslahah is also not widely acknowledged as the ends of mankind. Perhaps only a very small number of Muslims who could identify this goal as ends in their economic activities. In final analysis, both theories of the economic agent are considered unrealistic for the very simple fact that they are somewhat detached from the actual behaviour in the real world. By adopting the incremental welfare to reflect the ends in economic pursuits, Islamic economics science could be deemed as being more reflective of the reality. 


\section{REFERENCE}

Acikgenc, A. (1996). Islamic Science, Towards a Definition. Kuala Lumpur: ISTAC, 1996.

Al-Buthi, M.S.R.(1973). Dhawabith Al-Maslahah Fi AsySyariah Al-Islamiyyah, Damaskus, MuassasahArRisalah.

Asutay, M. (2007). Conceptualisation of the second best solution in overcoming the social failure of Islamic finance: Examining the overpowering of homoislamicus by homoeconomicus. IIUM Journal of Economics and Management 15, no. 2 (2007): 167-195

Azizy,S.H.(2014). Mendudukkan Kembali Makna Kesejahteraan dalam Islam. Ponorogo: Center for Islamic and Occidental Studies.

Az-Zuhaili, W. (2001). At-Tafsir al-Wasit. Damaskus: Dar al- Fikr

Broome, J. (1991). Utility. Economics and Philosophy, 7(01), 1-12.

Calnitsky, D., Dupuy-Spencer, A. (2013). The economic consequences of homo economicus: neoclassical economic theory and the fallacy of market optimality, The Journal of Philosophical Economics, 6(2). pp.1-26.

Farooq, M. O. (2011). Self-interest, Homo Islamicus and Some Behavioral Assumptions in Islamic Economics and finance. International Journal of Excellence in Islamic Banking and Finance, 1(1), 52-79

Furqani, H. (2015). "Individual and Society in an Islamic Ethical Framework: Exploring Key Terminologies and the Micro-Foundations of Islamic Economics." Humanomics Vol. 31 No. 1, pp. 74-87. 
Gilad, B., Kaish, S., Loeb, P.D. (1987). Cognitive dissonance and utility maximization: a general framework. Journal of Economic Behaviour and Organization, 8, pp. 61-73.

Gintis, H. (2000). Beyond homo economicus: evidence from experimental economics. Ecological Economics, 35, pp. 311-322.

Hasan, Z. (2011). Scarcity, self-interest and maximizationfrom Islamic angle. MPRA Paper. No. 29414, posted 08. March 2011 / 06:20

Hossain, B. (2014). Economic rationalism and consumption: Islamic perspective. International Journal of Economics, Finance and Management. 3(6), pp. 274-281.

Hosseini, H. (1992). From homo economicus to homo Islamicus: the universality of economic science reconsidered. In: Bina, C. \&Zanageh, H. (Eds.). (1992). Modern Capitalism and Islamic Ideology in Iran. St. Martin's Press, New York, USA.

Juster, F.T. (1990). Rethinking Utility Theory. The Journal of Behavioural Economics. 19(2), pp. 155-179.

Kahf, M. (2003). Islamic economics: notes on definition and methodology. Review of Islamic Economics. 13, pp. 23-47.

Khan, M.A. (2013). Reconstruction of Economics Based on the Paradigm of Tawhid: Present Challenges and Future Prospects. Keynote address for the First World Congress on Integration and Islamicisation of Acquired Human Knowledge. IIUM Malaysia.

Kuran, T. (1996). The discontents of Islamic economic morality. AEA Papers and Proceedings: Linkages Between Economics and Religion, 88(2), pp. 438-442.

Mahyudi, M. (2016). Rethinking the concept of economic man and its relevance to the future of Islamic economics. Intellectual Discourse, 24(1), 111-132. 
Mahyudi, M., Aziz, E. A. (2017). Rethinking the structure of Islamic economic science: the universal man imperative. International Journal of Economics, Management and Accounting. 25(2), 227-251.

Mirakhor, A. (2007). A Note on Islamic Economics. Jeddah: IRTI, 2007

Pettit, P. (1995). The virtual reality of homo economicus. TheMonist, 78(3). pp. 308-329.

Roberts, R. (2014). Sympathy for Homo Religious. Econ Journal Watch, 11 (2): 227-232

Sen, A. (1991). Utility: ideas and terminology. Economics and Philosophy, 7(2), pp. 277-283.

Shams, R. (2004). "A Critical Assessment of Islamic Economics." 281. Hamburg, Germany.

Siddiqi, M. N (1998): Teaching Economics in Islamic Perspective, Jeddah: ScientificPublishing Centre, King Abdulaziz University. In Hasan, Z. (2011). Scarcity, self-interest and maximizationfrom Islamic angle. MPRA Paper. No. 29414, posted 08. March 2011 / 06:20

Siddiqui, S. A. (2011). Defining economics and Islamic economics. Review of Islamic economics, 15(2), 113142.

Simon, H. A. (1972). Theories of bounded rationality. In C.B. McGuire et.al. (Ed). Decision and organization. Amsterdam: North-Holland Publishing Company, 161-176.

Van Witteloostuijn, A. (1988). Maximising and satisficing opposite or equivalent concepts? Journal of Economic Psychology. 9(3), pp. 289-313.

Wan Daud, W. M. N (2001). Budaya Ilmu dan Gagasan 1 Malaysia Membina Negara Majudan Bahagia, Putrajaya: Akademi Kenegaraan BTN. 